\title{
legelivet
}

På disse sidene i Tidsskriftet - legelivet - finner du stoff om legers liv.

Her er det presentasjon av arbeidssteder, nyhetssaker, nye doktorgrader,

nye spesialister og minneord. Alt samlet på ett sted - så du kan følge enda bedre med.

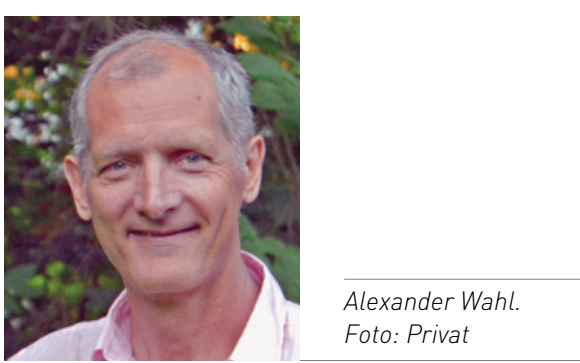

Alexander Wahl (f. 1963) er spesialist i allmennmedisin og arbeider ved Kurbadet legesenter. Han er også redaktør for primærhelsetjenesten i Helsebiblioteket.

\section{Legen fra helvete}

\section{Av og til trenger vi en klok kollega til å peke ut riktig kurs.}

De siste to årene har jeg deltatt i tre ukeskurs for å bli veileder i allmennmedisin. På disse kursene har jeg møtt et knippe flotte kolleger. Gjennom tett gruppearbeid, måltider og turer i skog og fjell er vi blitt godt kjent. Etter hvert kom historiene. Dr. Kompetentog-erfaren fortalte om hvordan hun i en periode ganske plutselig var blitt legen fra helvete.

Hun hadde mottatt en klage fra en pasient, klagen var også sendt til Norsk pasientskadeerstatning. Pasienten klaget på at legen ikke hadde oppdaget en kreftsvulst tidlig nok. Pasienten hadde vært deprimert, og dette hadde naturlig nok fanget legens oppmerksomhet. Etter at klagesaken dukket opp, startet dr. Kompetent-og-erfaren en indre dialog. Hun luftet tankene sine for en kollega. «Du må forstå at du er anklaget. Du er utsatt for angrep. Du må forsvare deg», var hans innstendige råd. Og med disse krigsmetaforene kom den store tvilen. Tvilen vokste til et monster. For å være sterk i forsvar bør man være sikker, men allmennpraksis er av natur et usikkert prosjekt.

Så en ettermiddag skjedde det en metamorfose. Min kollega holdt dommedag over seg selv og dømte hardt og nådeløst. Hun var i egne øyne inkompetent, men ikke bare det hun var ufølsom og ond. Hennes kolleger på kontoret prøvde å trøste, men trøsten prellet av - for de hadde ikke innsett Sannheten. Så det daglige virket fortsatte, men legen fra helvete fungerte ikke så bra som før. Hun var blitt usikker og spredte sin angst til pasientene. Det negative selvbildet ble forsterket. Hun vurderte å slutte som lege.

Heldigvis hadde legen en klok kollega, en kollega som ikke bagatelliserte det hun hadde gjort. En kollega som heller ikke dømte henne for hva hun hadde gjort eller tenkt. Han klarte å stå i det og holde ut hennes smerte, ta utgangspunkt $i$ at det er ille å være legen fra helvete - skikkelig ille. Sammen utforsket de handlingsalternativene: slutte som lege eller fortsette. De ble enige om at hun skulle forsøke å gå videre i legepraksisen. «Men», sa den kloke kollega, «da må du gjøre én ting annerledes. Du må sjekke om du har rett. Ved hvert møte med pasient, kollega eller sekretær må du ha antennene ute. Responderer de på deg som om du var legen fra helvete? Er dette virkelig sant?».

Denne regelmessige realitetssjekken gjorde til at legen fra helvete langsomt gjenvant fotfestet. Pasientmøtene var betydningsfulle, hun var en høyt verdsatt kollega. Hun følte det og tok det innover seg. Hun hadde tatt feil. Følelser kan man ikke alltid stole på. Nå er hun igjen blitt Dr. Kompetentog-erfaren - supererfaren. Og alle vi som hørte på denne historien måtte kjenne litt på egne nederlag og glede oss over at Dr. Kompetent-og-erfaren hadde gjenoppstått.

\section{Alexander Wahl}

alexanderwah132@gmail.com 